INTERNATIONAL DESIGN CONFERENCE - DESIGN 2018

https://doi.org/10.21278/idc.2018.0318

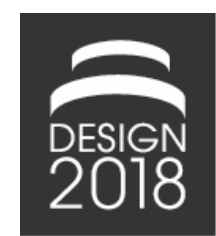

\title{
GENERATIVE HERITAGE: DRIVING GENERATIVITY THROUGH KNOWLEDGE STRUCTURES IN CREATIVE INDUSTRIES. LESSONS FROM CUISINE
}

\author{
D. Carvajal Pérez, A. Araud, V. Chaperon, P. Le Masson and B. Weil
}

\begin{abstract}
Sometimes, a designer needs to share a "creation heritage" to support the generativity of his pairs, in the form of a book. What should be its content? The literature has shown that knowledge in such books might be fixating or defixating, leading to inconclusive results. Using recent advances in design theories we model the features of a heritage oriented towards generativity. Relying on the literary tradition in Cuisine, we validate our model. We show that transferring knowledge implies sharing objects structure, value criteria, desired unknowns, progress principles, and creative reasoning.
\end{abstract}

Keywords: design creativity, knowledge management, knowledge sharing, $C-K$ design theory, generativity

\section{Introduction}

How can knowledge heritage be generative? The transfer of knowledge is a well-known issue in engineering design. Several studies have underlined the importance of transferring knowledge in order to avoid losses of know-how after losing an employee (Dalkir, 2011), to reproduce best practices in geographically dispersed firms (Szulanski, 1996), to avoid rediscovering what is already known (Szulanski et al., 2004) and to transfer knowledge between partner organizations (Schulze et al., 2014). However, the literature is rather inconclusive concerning the transfer of resources for creativity. Moreover, is it possible to "transfer" a knowledge OF creativity? What should be transferred in order to assure that the transfer keeps not only the heritage but keeps also the "creative" spirit in it? Indeed, this last facet of transferring knowledge heritage is not self-evident: in the one hand, research has highlighted that knowledge could limit and kill creativity, as knowledge can be fixing due to easily available knowledge (Jansson and Smith, 1991) and as core capabilities can transform in core rigidities under certain circumstances (Leonard-Barton, 1992). In the other hand, scholars and practitioners have described the positive effects of knowledge on creativity and ideation, especially as knowledge quantity can influence the number of possible idea recombination (Mednick, 1962; Scott, 1999; Young, 2015), as past knowledge helps to recognize the value of new knowledge (Cohen and Levinthal, 1990), and as past knowledge can be a source for innovating product functionalities and meanings (Messeni Petruzzelli and Savino, 2014; De Massis et al., 2016). Hence, we are invited to ask: how can one transmit a "creative heritage"?

To answer this question we will rely on two building blocks: First, recent progresses in design theory (for a synthesis, see (Hatchuel et al., 2018)) shows that knowledge plays an important role in generativity and that the structure of knowledge might be the critical feature to support creativity. Hence it might be possible to derive, from Design Theories, hypotheses on how an "heritage" can be a 
"creative heritage" or a "generative heritage". On the other hand, we will illustrate our findings thanks to the analysis of "generative heritages" in creative, cultural and luxury industry. This is particularly relevant because in those industries heritage plays a critical role, contributing to brand and product differentiation (Briot and De Lassus, 2014), bringing brand identity and consumer appeal (Urde et al., 2007; Hudson, 2011), being associated with brands' authenticity and reliability (Beverland, 2005, 2006) and contributing to the perceived value of the brand (Wuestefeld et al., 2012). Using cuisine books, written by important chefs that were eager to share their knowledge heritage and generativity with their colleagues, we will characterize the properties possessed by generative heritages. Furthermore, we propose a classification of types of generativity and we will show how the generativity associates with those properties.

In this paper, we first review the literature on design, knowledge management, and transfer of knowledge for generativity. We then propose a theoretical model describing the properties of a generative heritage, and their relationship with several types of generativity. We then illustrate our theoretical model thanks to generative heritages from cuisine and finally we conclude the paper and propose some clues for future research.

\section{Theoretical background}

What do we know about generative heritages or making a heritage "creative"? Innovation and design are knowledge dependent and knowledge creating activities (Nonaka, 1994; Madhavan and Grover, 1998; Pitt and Clarke, 1999; von Krogh et al., 2000; Hatchuel and Weil, 2009). Hence, the transfer of knowledge heritage is a subject of paramount importance for the survival and performance of organizations. Knowledge, skills and competences transfer is important in order to avoid losses of knowhow (Dalkir, 2011), to reproduce best practices in geographically dispersed firms (Szulanski, 1996), to avoid rediscovering what is already known by organizations (Szulanski et al., 2004) and to transfer knowledge between partner organizations (Schulze et al., 2014). Hence, organizations are confronted to managing both spatial transfer of knowledge from one individual, team, department or geographical division to another (Argote et al., 2000), as well as transfer of knowledge through time (De Massis et al., 2016).

However, transfer of knowledge is often difficult and time consuming (Arrow, 1969; von Hippel, 1994; Szulanski, 1996, 2000; Tsai, 2001; Goh, 2002). Indeed, several factors may affect knowledge transmission according to the stage of the process of knowledge transfer, and have its origins in characteristics of the knowledge transferred, of the source of knowledge, of the recipient of knowledge and of the context (Szulanski, 1996, 2000). Nonetheless, the major barriers to internal knowledge transfer are knowledge-related factors such as the recipient's lack of absorptive capacity, causal ambiguity, and an arduous relationship between the source and the recipient (Szulanski, 1996).

Furthermore, the transfer of knowledge should ensure the maintenance and elicitation of the generative capacity of designers. We know certain cases in which a knowledge source (a designer) wanted to transfer a knowledge heritage to a recipient designer in order to make him more generative. Thus, we know some cases of generative heritages in domains like engineering design and industrial design:

Nagel et al. (2017) reported how the need to establish instructional resources and best practices for teaching bioinspired design, lead those authors to teach to their students $\mathrm{C}-\mathrm{K}$ design theory and bioinspired design. This generative heritage helped engineering students to incorporate to their knowledge bases design operators. These operators guided the exploration and transformation of both students and biology's knowledge bases, enabling the discovery and knowledge transfer process of bioinspired design from biology to engineering as well as from engineering to biology.

Le Masson and Weil (2013) studied how engineering design theories and methods, that originated in Germany, gave to learners theories for helping them design new objects. Those theories gave to students both a language to describe existing objects, as well as frameworks to guide the elaboration of still unknown objects with the help of known objects. They were characterized by the mobilization of several languages of the object (namely functional, conceptual, embodiment and detailed languages) in a sequential manner and provided designers with theories of controlled expansion based on languages of the unknown. 
Le Masson et al. (2016) reported how Bauhaus courses gave elements to design students not only to understand old and new styles, but also to create new styles. The authors described that thanks to Bauhaus' teaching, students were able to create a knowledge structure characterized by non-modularity and non-independence. That is, at each step of the design process, the designer could not use a deterministic law in order to choose the next property of the object. Moreover, each new step was critical and influenced the whole work. Furthermore, thanks to Bauhaus teaching, designers were able to learn a design process that helped them to be generically creative. This design process was based on a progressively accumulation of general languages on the object in a robust way. This accumulation was based on two principles: First, even if each step of the design process addressed 'parts' of the object, each step also addressed an aspect that was valid at the level of the whole object. Hence, each steps leaded to the 'validation' of one dimension of the 'whole' object. Second, the process of language accumulation was neither deterministic nor modular. It was based on transitions between languages that kept the possibility of multiple paths open at each level, and propagated the originality won at one level to the following level.

This literature review helps us understand that knowledge transmission depends on the recipients' previous knowledge and ability to recognize the value of new knowledge (Szulanski, 1996). Hence a recipient designer with good design capacities should exhibit a higher generativity after having assimilated a generative heritage with respect to a lesser prepared designer. Furthermore, knowledge transfer implies also the transfer of capacities to use this knowledge to design: heritage contains design operators. Moreover, we can also recognize that knowledge transfer can elicit a gain of different kinds of generativity, as the newly acquired knowledge base can help designers to design new objects: 1) without producing additional knowledge, 2 / while facilitating knowledge expansions, to fill identified knowledge voids either present in the new knowledge base, or already present in the recipient knowledge base, or 3) while enabling the generation of new unknowns, not originally present in the design space of the recipient designer nor in the design space carried by the heritage.

Hence we are motivated to answer to the question: what are the characteristics of a knowledge heritage that enables a recipient designer to obtain a certain generativity?

\section{Theoretical proposition}

\subsection{Generative heritage}

Let us define a generative heritage $(\mathrm{H})$ as a set of knowledge and concepts, that when transferred from a source designer $(A)$, and assimilated by a recipient designer $(B)$ it enhances recipient's designer generativity $(G)$. We understand generativity as the capacity to generate a novel object with desired properties, different from any other known object and that cannot be deduced from existing knowledge (Hatchuel et al., 2011; Le Masson and Weil, 2013). Hence, in order to characterise the effects of a knowledge heritage on generativity, we need a conceptual framework that let us model the generative reasoning responsible both for rule-based and innovative design. This framework must take into account the role of knowledge in the generative process, as well as knowledge expansions (i. e. the emergence of new knowledge domains, new knowledge structures and new description languages). In consequence, we will model a generative heritage using Design Theories. Indeed, Design Theories, and in particular $\mathrm{C}-\mathrm{K}$ Theory, have proven their utility to model with success the generative reasoning of several creators like engineers, architects, designers, and artists (Hatchuel, 2005; Hatchuel and Weil, 2009). C-K theory models the design process as an interaction of two spaces: the concept space (C) and the knowledge space $(\mathrm{K})$. Both spaces are constituted by propositions but they differ in terms of structure and logics: The knowledge space is constituted by propositions with a logical status (they are true or false), while the concept space is constituted by propositions without a logical status with respect to the knowledge space propositions. Concepts are interpretable propositions using the propositions in the $\mathrm{K}$ space. However, they are undecidable using this same knowledge, that is, we cannot say whether they are true or false. A design process starts with an initial Concept $\mathrm{C} 0$, an undecidable proposition in $\mathrm{K}$ space, formulated in a manner "There exists an object $\mathrm{X}$ having some properties Pi". The design process finishes when knowledge expansions guarantee the logical status of the proposition in the $\mathrm{C}$-Space. 
Taking advantage of the $\mathrm{C}-\mathrm{K}$ theory, we can model the design reasoning of designer B as a C-K map, containing a space of knowledge $(\mathrm{K})$, a space of concepts $(\mathrm{C})$, and a set of operators representing the interactions between those two spaces $(\mathrm{K}->\mathrm{K}, \mathrm{K}->\mathrm{C}, \mathrm{C}->\mathrm{K}, \mathrm{C}->\mathrm{C})$. Designer B has a knowledge base $\left(\mathrm{K}_{\mathrm{B}}\right)$ and a set of instantiated concepts $\left(\mathrm{C}_{\mathrm{B}}\right)$ associated to his knowledge base. To accomplish a design task, designer $\mathrm{B}$ has to navigate between the $\mathrm{C}$ and $\mathrm{K}$ spaces thanks to operators, while expanding his knowledge base and partitioning his concept space.

We can now develop our definition of a generative heritage as a collection containing a knowledge base $\left(K_{\mathrm{H}}\right)$, a reservoir of concepts associated with this knowledge base $\left(C_{\mathrm{H}}\right)$, and a set of $C-K$ operators.

We will model $\mathrm{K}_{\mathrm{H}}$ as composed by two subspaces: the object structure and the value criteria. And $\mathrm{C}_{\mathrm{H}}$ as also composed by two subspaces: the knowledge voids, and the progress principles:

The object structure subspace (DPs) represents the several elements and their dispositions that the designer can use to design. We can find a parallel between this definition of the object structure and the design parameters of Axiomatic Design (Suh, 1990, 2001). The different elements of the object structure can be related in several forms, through classifications, taxonomies, and facets. And those relationships can vary in their degree of strength and explicitness.

The value criteria subspace (FRs) contains designers and user's beliefs, expectations, needs of desired outcomes. It is manifested through claims and sentences of desired states, desired functions, desired functional requirements, and performance criteria. It can be modelled as a functional domain (FR).

Objects and conceptual models can be interpreted as associations between elements of the value criteria subspace and elements of the object structure subspace.

The knowledge voids (mDPs) correspond to identified but missing elements of the object structure.

The progress principles (PPs) are identified value criteria that possess no associated design parameters of the objects structure. They correspond to value criteria that are still waiting for a "mapping" to the objects structure, attributes, or properties.

Furthermore, we propose to differentiate among 4 types of generativity associated with the combination of the design capacities of designer B and of the knowledge heritage (Figure 1):

Type 0. Selection generativity (Figure 1.a): Inside the knowledge heritage, the source designer has already created and validated a set of objects in accordance with his FRs. Generativity Type 0 consists in the basic capacity of designer B to select and reproduce the new objects presented in $\mathrm{K}_{\mathrm{H}}$.

Type I. Combinatorial generativity (Figure 1.b): The conceptual and generative models provided by the expanded knowledge base of designer $\mathrm{B}\left(\mathrm{K}_{\mathrm{B}} \cup \mathrm{K}_{\mathrm{H}}\right)$, augment recipient designer's generativity as a result of the combination of extant elements in both knowledge bases. Furthermore, the new knowledge base provides validation capacities to assure the alignment between $\mathrm{K}_{\mathrm{H}}$ and associated $\mathrm{C}_{\mathrm{H}}$ during the design process. However, in type I generativity, new knowledge expansions are dismissed or discouraged. Hence, recipient designers can modify an object contained in $\mathrm{K}_{\mathrm{H}}$ to prepare a new object while using the DPs and FRs proposed by $\mathrm{K}_{\mathrm{H}}$, they can compose new objects by combining the DPs contained in $\mathrm{K}_{\mathrm{H}}$, and they can recombine old DPs, from $\mathrm{K}_{\mathrm{B}} \cup \mathrm{K}_{\mathrm{H}}$.

Type II. Expansive generativity (Figure 1.c): In type II generativity, the generativity is not only the result of a combination of elements in $\mathrm{K}_{\mathrm{B}} \cup \mathrm{K}_{\mathrm{H}}$ but the result of new knowledge expansions. That means that knowledge expansions are encouraged, expected and primed. They concern both the extension of the elements of the object structure (DPs) and of the elements of the Value Criteria (FRs). They can be guided by several mechanisms: $1 /$ Identified voids in the object structure: $\mathrm{K}_{\mathrm{H}}$ can explicitly identify missing but desirable DPs (mDPs) and that are not contained in $\mathrm{K}_{\mathrm{B}} \cup \mathrm{K}_{\mathrm{H}}$. Hence, a knowledge expansion is necessary; 2/ FRs without associated DPs: Sometimes, value criteria are not associated with elements of the object structure. Hence, knowledge expansions are also necessary; 3/ In certain occasions, the knowledge heritage gives guidance concerning where to search for filling the voids or mapping the FRs to DPs.

Type III generativity (Figure 1.d): In type III generativity, recipient designer is able to generate new unknowns with respect to the concepts already contained in both knowledge bases, that is to generate $\mathrm{C} 0$ not in $\mathrm{C}_{\mathrm{B}} \cup \mathrm{C}_{\mathrm{H}}$. This class of generativity is possible thanks to the expansion of $\mathrm{K}_{\mathrm{B}} \cup \mathrm{K}_{\mathrm{H}}$ in directions primed by $\mathrm{K}_{\mathrm{H}}$, and thanks to the research on new languages to describe the objects to be designed. 
a) Type 0 generativity

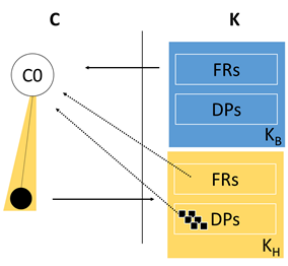

b) Type I generativity

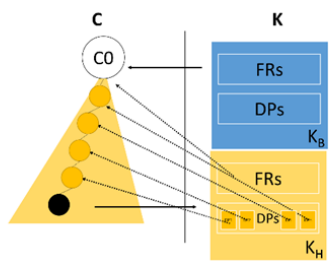

c) Type II generativity

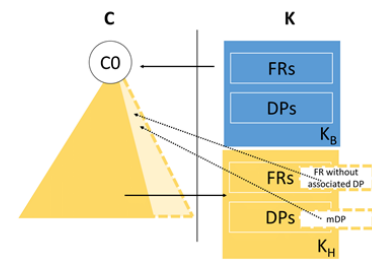

d) Type III generativity

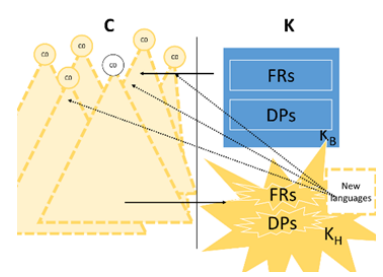

Figure 1. C-K theory representation of the 4 types of generativity

\subsection{Hypothesis}

In the following sections we will validate and illustrate our theoretical proposition by answering to our research question through the following hypothesis: H1: Generative heritages contains an object structure and value criteria in the $K$-space, and knowledge voids and progress principles in the $C$ Space; H2: Generative heritages possess at least Type 0 generativity; H3: Generative heritages possess Type I generativity; H4: Generative heritages possess Type II generativity; and finally, H5: Generative heritages possess Type III generativity.

\section{Methodology}

We will examine several "generative heritages" of a same domain in the creative and luxury industry: cuisine. Through history, cuisine has constantly been in search of novelty (Beaugé, 2013). Furthermore, several renown Chef-creators have formalized their knowledge, and have transferred it to their pairs, in order to share with them a certain generative capacity (Fink, 1995; Beaugé, 2013; Rambourg, 2010; Opazo, 2016). Hence, cuisine books offer to us a considerable amount of material thanks to which we can study generative heritage properties, and its relationship with generativity. We proceeded through a 2 stages process. First, starting from a corpus of cuisine books written in several epochs and languages, we retained the books that claimed to be "generative heritages". Then, we characterized the types of generativity and the characteristics of the knowledge heritage.

\subsection{Book selection}

In order to constitute a corpus of generative heritages, we have first selected a collection of 40 cuisine books written in different years from 1651 to 2017, available in French, Spanish or English language. This initial sample was selected because of their influence in the cooking world as described by sociologists and historians (Rambourg, 2010; Beaugé, 2013; Opazo, 2016). The sample was also complemented by a selection of published books as recommended by experienced cuisine chefs to one of the authors. Using our theoretical proposition described in Section 3, we retained only the books in which the author claimed to have written a generative heritage as evidenced by three types of claims: The book describes a recipient designer (Collective value claim), it intends to give a complete heritage to the recipients (Completeness claim), and the heritage is intended to promote generativity (Novelty claim). Hence, we analysed the contents of the title, the preface, the introduction and the foreword of each book in order to search for the presence of each one of the three claim categories. Table 1 contains a description of each claim category and an example of found verbatims in books.

In total, we classified 13 books as "generative heritages". In the rest of the paper, we will call a generative heritage a collection of books written by a same author or collective. We will illustrate our propositions using the generative heritages of three authors: 1/ François La Varenne writer of "Le Cuisinier François" (The French Cook) (La Varenne, 1651), 2/ Auguste Escoffier writer of "Le Guide Culinaire, aide-mémoire de cuisine pratique" (The Complete Guide to the Art of Modern Cookery) and Le Livre des Menus (The Menu Book) (Escoffier, 1903, 1907, 1912a, 1912b, 1921), and 3/ elBulli, a collective lead by the chef Ferran Adrià, writers of several books describing the management of the elBulli restaurant (Adrià, 1998; Adrià et al., 2014). 
Table 1. Description and examples of the claim categories used to distinguish the "generative heritages"

\begin{tabular}{|c|c|c|}
\hline Claim Category & Description & Example \\
\hline Collective value & $\begin{array}{l}\text { The author claims to define a target } \\
\text { audience for his work, and consider } \\
\text { his target as creators/designers }\end{array}$ & $\begin{array}{l}\text { "My intention is not to shock nor to offend anyone. [...] But to serve and help } \\
\text { those who will need, several of whom do not have the experience, nor the present } \\
\text { memory, and who do not want or do not dare to become fully involved in learning } \\
\text { what they do not know, in part due to glory, in part due to consideration. } \\
\text { [...] That is why, while particularly appreciating those of my profession, I } \\
\text { thought I should share with them the little I know [...]" (La Varenne 1651) }\end{array}$ \\
\hline Completeness & $\begin{array}{l}\text { The author claims to describe the } \\
\text { state of the art of the cuisine and } \\
\text { defends his work as a sufficient } \\
\text { material to practice the cuisine } \\
\text { according to the most up to date rules }\end{array}$ & $\begin{array}{l}\text { "I wanted to do a tool more than a book and, while letting each one to operate } \\
\text { according to his personal view, I was keen, [...], to fix, at least in principle, the } \\
\text { traditional basis of work" (Escoffier 1921) }\end{array}$ \\
\hline Novelty & $\begin{array}{l}\text { The author claims having taken a } \\
\text { new and different approach with } \\
\text { respect to other authors. He might } \\
\text { claim improving extant knowledge } \\
\text { bases or breaking with the old } \\
\text { knowledge bases. }\end{array}$ & $\begin{array}{l}\text { "[...] It was Ferran Adrià's appointment as sole head chef in } 1987 \text {, however, that } \\
\text { signalled the real turning point in the restaurant's creative development. It finally } \\
\text { closed its doors on } 30 \text { July } 2011 \text {. During that time the field of gastronomy } \\
\text { changed enormously, and it would have evolved very differently without the } \\
\text { work of Ferran Adrià. During his } 27 \text {-year tenure as head chef at elBulli, he and } \\
\text { his team began a sustained programme of innovation that has had no parallel in } \\
\text { the food world." (Adrià et al. 2014) }\end{array}$ \\
\hline
\end{tabular}

\subsection{Book analysis}

Objects structure: In order to understand the objects structure proposed by the books of a same author, we have done first a text analysis. We have analysed the introduction of each book in order to find the general framework proposed by the author, as well as the actions undertaken by him and their consequences. Thanks to the introduction we have also analysed the environment in which the book was written, and the author's objectives. We have analysed the language used by the authors in the table of contents, as well as in the introductory paragraphs of each chapter. We have also done an analysis of the general logics and rules proposed by each author. We have complemented our approach with the analysis done by other scholars (mostly historians or sociologists). Once we have understood the books' object structure, we compare each structure with the other two structures. Value criteria: To elucidate the value criteria embedded in the knowledge base, we have done a text analysis in search for definitions of "desirable", and "good things" as expressed by the author. We also searched to highlight how those value criteria are linked to elements of the object structure concerning the production (process or routines descriptions) or the validation (time, temperature) processes. In addition, we conducted a text analysis in order to find author's recommendations to fulfil those requirements. That is, the relationships between value criteria and objects structure. Knowledge voids and progress principles: To elucidate the knowledge voids and the progress principles proposed by the authors, we have done a text analysis in order to find the "holes" clearly identified or suggested by the author and his structure. Moreover, we searched for author's recommendations to the manner of "filling" those "holes".

\section{Results and discussion}

\subsection{H1: Generative heritages contains an object structure and value criteria in the K- space, and knowledge voids and progress principles in the C-Space}

François Pierre de La Varenne (1618-1678) wrote the cookbook "Le Cuisinier françois", published for the first time in 1651 (La Varenne, 1651). He was chef to the Marquis d'Uxelle. Until La Varenne's work, most cookbooks were written by maitres d'hôtel instead of by cooks (Beaugé, 2013). Before him, books were simply recipe repositories without much structure (Beaugé, 2013). La Varenne's book organize the recipes according to a rational, modular logic (Fink, 1995; Beaugé, 2013), creating an object structure that was useful to the management of the kitchen of his epoch: Products, like meats or vegetables, are listed and classified according to their availability in a certain moment of the year. For example, La Varenne specifies that ortolans (a particular species of little birds), could be found from Easter (in March, April) until the feast of St Remy (in January), while suckling pigs were available from the feast of St Remy until times of Lent (in March). Basic recipes, useful for several culinary preparations, are identified and described. This is the case for example of broths, useful for preparing several types of soups; as well as mushroom juice, useful for sauces and ragouts. Furthermore, recipes are separated by service (in Soups, 
Entrées, Second service, and Entremets). And they are also classified according to the liturgical year in "fat days", "lean days" and times of Lent. He details methods of preparation and conservation of several elements intervening during the cooking process as is the case for sauces, and "liaisons".

Auguste Escoffier (1846-1935) was a renowned French cook, director of the kitchens at the Savoy Hotel and at the Carlton Hotel in London. His master piece, "Le Guide Culinaire" (The Complete Guide to the Art of Modern Cookery) knew 4 editions between 1903 and 1921 and is still a reference book for chefs all over the world. Escoffier separates his object structure in two big categories: 1/ the fundamental elements of cooking, and 2/ the recipes and mode of procedures. This separation is explicit in the English edition of "Le Guide Culinaire" appeared in 1907 (Escoffier, 1907), however it is subtle exposed in French versions of the book. The fundamental elements of cooking constitute basic definitions and procedures, common for different culinary preparations in Escoffier's knowledge base. This is the case of sauces and garnishes, root elements used for several culinary preparations. Moreover, culinary operations are also part of the fundamental elements. Escoffier establish precise definitions of what objects like Sauces and Soups are. He describes for example, that a Sauce is composed by a juice (like beef stock) and a roux (a mix of flour and butter that thickens the sauce). The recipes and procedures detail different preparation routines for obtaining the several type of dishes composing a Menu. He uses a rich nomenclature to identify and differentiate his recipes (for example, the purée à la Conti is a purée made of lentils, while the purée à la Condé is made of beans). Furthermore, Escoffier proposes a list of the different garnishes that can accompany each dish, and the sauces that might be used. Escoffier classifies recipes according to their order of presentation in the Menu. And he provides also detailed classifications inside each type of culinary preparation. Hence, for example, he proposes a classification of soups in clear and thick soups. The former are divided in plain and garnished consommés, and the latter comprise the Purées, Veloutés, and Creams, all different types of culinary preparations that he defines in his work. Escoffier's generative heritage identifies FRs like simplicity, rapidity, as well as client satisfaction.

elBulli was not a person but a restaurant led by the chef Ferran Adrià. elBulli's object structure clearly distinguishes several modules, and make an effort to work with the identity of the objects of cuisine: The module Products contains the set of raw materials and elements that can be used for conceiving a dish. They introduce a distinction between two kinds of products: non-elaborated products (like grapes or raw meat) and elaborated products (like wine, oil, chocolate or sugar). ElBulli gives to the reader an exhaustive list of products and new products used by the restaurant in particular years. They present the efforts they made to research new products coming from all around the world, as well as to how to use the normally discarded parts of products (for example they report the use of granadillas' skin). The module Elaborations contains a list of classes of culinary preparations that are classified according to a classification system that take roots on older classification like those of Carême and Escoffier. However, they extend the classical words with new ones issued from new techniques, or from foreign classifications (like "Spherification", "Nitro" or "Sashimi"). This classification system differs from the name of the courses used in elBulli. Techniques (applied to products) presents the several techniques and preparation modes undergone by one or several Products as well as by Elaborations. Examples of techniques are Cutting, Sphérification and Lyophilisation. Moreover, elBulli introduces the notion of Concept, a sort of generalisation of Carême's and Escoffier's nomenclature: for elBulli, a sauce is a Concept; a soup is a Concept. There is a relationship with the notion of elBulli's Concept and objects identities. In Technology, elBulli exposes the different tools, devices and utensils intervening in the transformation of Products and Elaborations. Typical culinary devices such as silicon moulds, frying pans and juice extractors are accompanied by freeze dryers, and coating drums, devices commonly used in chemistry laboratories. Recipes: During its existence, elBulli created several dishes. However, only 1846 dishes were given a number identifier, a name, and were served in the restaurant. They are inscribed in a repertory called the "Evolutive Catalogue". Furthermore, dispatched in several modules, elBulli works on a language of the reception of the dishes. They describe how the five senses play a role in the perception of the culinary preparations. elBulli identifies FRs like novelty, knowledge acquisition, and client satisfaction.

Hence, all three analysed generative heritages propose object structures composed by several categories of DPs. However, the nature of the categories is different for each generative heritage. This differences, as well as the FRs, mDPs and PPs will have some consequences in the generativity that we will explore in the next subsections. 


\subsection{H2: Generative heritages possess at least type 0 generativity}

The three analysed generative heritages contain a rich set of recipes that enable recipient designers to reproduce a huge amount of culinary preparations thanks to the presence of lists of ingredients, and descriptions of successive culinary operations. Furthermore, inside each book, authors expose their identified value criteria and propose to readers already tested recipes responding to those value criteria. Hence, recipient designers can choose one or several recipes from a previously validated list of dishes. Furthermore, the nomenclature introduced by the three shown generative heritages play a paramount role in Type 0 generativity, as selecting a named recipe among a set of validated recipes, is probably economic in terms of cognitive resources. For example, using La Varenne's generative heritage, a recipient designer can choose between reproducing a Soup of partridge and cabbage, or a Soup of duck and turnips; while using Escoffier's generative heritage, the designer can reproduce a Soup Olla-Podrida (made with partridge) or a Danish soup (made with duck).

\subsection{H3: Generative heritages possess type I generativity}

Table 2. Generative heritages possessing type I generativity shows different forms of DPs recombination

\begin{tabular}{|c|c|c|c|}
\hline & François Pierre La Varenne & Auguste Escoffier & elBulli \\
\hline $\begin{array}{c}\text { Modifying a recipe } \\
\text { contained in the } \\
\text { book to prepare a } \\
\text { dish while using } \\
\text { DPs proposed by the } \\
\text { book }\end{array}$ & $\begin{array}{l}\text { "All kind of meats, like beef, sheep, lamb, pork, from } \\
\text { everywhere, can be used to prepare a ragout [...], but take care of } \\
\text { clean them, and make sure that they have a good taste." }\end{array}$ & $\begin{array}{l}\text { "The principle of composition of garnishes, as of all culinary } \\
\text { preparation, is intangible. If in several cases, modifications are } \\
\text { required, they only imply a change in the disposition or in the } \\
\text { form, according to the object to which the garnish is intended, } \\
\text { and not to a change in the elements." }\end{array}$ & (No supporting verbatim found) \\
\hline $\begin{array}{c}\text { Composing a new } \\
\text { dish using the DPs } \\
\text { contained in the } \\
\text { book }\end{array}$ & $\begin{array}{c}\text { "All kind of fat or lean pastry, that can be eaten hot, are seasoned } \\
\text { in the same way, following the type of used meat. You can even } \\
\text { put garden garnishes, like mushrooms, truffles, asparagus, egg } \\
\text { yolk, artichoke heart, capers, chards, pistachios. To flesh pies, } \\
\text { besides the garden garnishes, you can use sweetbreads, kidneys, } \\
\text { crests, etc." }\end{array}$ & $\begin{array}{l}\text { "Fonds de cuisine } \\
\text { Before undertaking the description of the different kinds of dishes } \\
\text { whose recipes I purpose giving in this work, it will be necessary } \\
\text { to reveal the groundwork whereon these recipes are built. } \\
\text { [...] } \\
\text { Indeed, stock is everything in cooking, at least in French cooking. } \\
\text { Without it, nothing can be done. [...] } \\
\text { Sauces } \\
\text { The fundamental basis of its work are the stocks. Either a brown } \\
\text { stock or "estouffade" for brown sauces; or white stock for the } \\
\text { Veloutés [...]" }\end{array}$ & (No supporting verbatim found) \\
\hline $\begin{array}{l}\text { Composing a Menu } \\
\text { using recipes } \\
\text { contained in the } \\
\text { book but modyfing } \\
\text { them. Usage of the } \\
\text { DPs and of the FRs } \\
\text { of the book }\end{array}$ & $\begin{array}{l}\text { "[...]. I have drawn up four services, in front of which you will } \\
\text { find the Table and then the speech. I have divided them according } \\
\text { to the several ways of serving the meal as used in the days of } \\
\text { meat, of fish, and of Lent. And particulary for Good Friday, I } \\
\text { have adjusted a lot of general things, for which you will see the } \\
\text { tables and the discourses. [...]" }\end{array}$ & $\begin{array}{l}\text { "In the different series that compose this work, I have roughly } \\
\text { gathered all kind of menus needed in the current circumstances of } \\
\text { culinary life. And if sometimes, their full application is difficult } \\
\text { or impossible, a simple imagination effort suffices for providing } \\
\text { the desired transformations, in order to conform them to their } \\
\text { destination." }\end{array}$ & (No supporting verbatim found) \\
\hline $\begin{array}{l}\text { Recombining DPs } \\
\text { contained in both } \\
\mathrm{KH} \text { and } \mathrm{KB}\end{array}$ & (No supporting verbatim found) & (No supporting verbatim found) & $\begin{array}{l}\text { "In } 2010 \text { we served three cocktails with a snack incorporated. } \\
\text { Although some of those preparations were cocktails as far as their } \\
\text { taste went, their structure was likened to that of a snack" }\end{array}$ \\
\hline
\end{tabular}

Type I generativity is the result of the combinatory power of a generative heritage. All three analysed generative heritages propose object structures composed by several categories of DPs (Table 2). However, the nature of the categories is different for each generative heritage. La Varenne talks of DP categories like Meats, Stocks, Sauces, Soups, Entrées, Second service, and Entremets, and the manners to prepare them. Escoffier proposes a set of basic DP categories like Sauces and Garnishes, and then a set of derived categories in accordance with the Menu of his epoch: Soups, Eggs, Relevées, Entrées, among others. elBulli pushes the classification system of its DPs and gains in generality to talk of DPs like Products, Techniques and Elaborations. Inside each category of DPs, the different generative heritages propose a set of elements (which in turn are also DPs). For example, inside the category Meats of La Varenne, we can find elements like chickens, lambs, or pheasants. Furthermore, the different object structures propose a complex language of composition with hierarchies inside it: In Escoffier's generative heritage, certain DPs like Stocks are the basis of several culinary preparations, like sauces. And one single Stock enables the elaboration of several different Sauces, which in turn give origin to several different dishes. Thus, recipient designers can use those modules and combine them to design new objects (dishes, or Menus) using several combinatorial strategies (Table 2): recipient designers can 
modify a recipe contained in the book to prepare a dish while using the DPs proposed by the book, they can compose new dishes by combining the DPs contained in the book, they can compose a Menu using recipes contained in the book but modifying them, using both the DPs and the FRs of the book, they can recombine old DPs, from the designers knowledge base or from $\mathrm{K}_{\mathrm{H}}$, (like the ingredients of a particular dish) with a new DP from $\mathrm{K}_{\mathrm{H}}$ (a new type of elaboration). Thus, for example using Escoffier's objects structure new objects can be created by replacing the principal ingredient of a recipe with another, or by variating some of the elements used as garnish. This is in accordance with Fink's description of La Varenne's cookbook as composed by several modules thanks to which a new dish can be "conceived as a modular structure with variants, following the laws of a system of assembly and disassembly." (Fink, 1995). Nonetheless, elBulli's generative heritage do not invite recipient designers to use strategies leading to Type I generativity as evidenced by the few number of verbatims found. This can be partially explained because more than a cookbook, elBulli literary production describes the restaurants life in search for novelty, subject of the next subsection.

\subsubsection{Generative heritages possess type II generativity}

Table 3. Generative heritages possessing type II generativity shows different forms of knowledge expansions

\begin{tabular}{|c|c|c|c|}
\hline & François Pierre La Varenne & Auguste Escoffier & elBulli \\
\hline Identified FRs & (No supporting verbatim found) & $\begin{array}{l}\text { Simplicity and Nutritional value } \\
\text { "We will take simplicity to the outmost limits. But, in the same } \\
\text { time, we will increase the flavor and nutritive value of dishes. We } \\
\text { will make them more light, more easily digestible for the weaken } \\
\text { stomachs; we will concentrate them; we will strip them of the } \\
\text { most part of their inert matter. [...]" }\end{array}$ & $\begin{array}{l}\text { Novelty, Knowledge of the extant, knowing the client and his } \\
\text { referential } \\
\text { "[..] The anxiety [of the cook] for discovering what has been } \\
\text { done, or what others are doing, for bring himself up to date and } \\
\text { for knowing the most recent interesting trends, is a factor of } \\
\text { paramount importance. [...]. It is not the same to cook for a diner } \\
\text { accustomed to go twice a year to a creative cooking restaurant, } \\
\text { compared to serve a person who constantly visit all the creative } \\
\text { restaurants in the world. The first one can be surprised by every } \\
\text { novelty, even the smallest one. The second one, will be able to } \\
\text { classify each new experience according to its merited value, } \\
\text { according to a scale composed by a wide range of parameters." }\end{array}$ \\
\hline Unknown desired DPS & (No supporting verbatim found) & $\begin{array}{l}\text { Food without inert matter } \\
\text { "[...]. From then on, a gradual change in the human dietary regime } \\
\text { will be inevitably required. Supposing that the same quantity of } \\
\text { active nutritional principles will be necessary to our grand- } \\
\text { nephew, they will search for them in food mostly stripped of } \\
\text { inert and useless matter, in a more concentrated nutrition, made } \\
\text { possible and necessary by a modification of the capacity of the } \\
\text { digestive organs." }\end{array}$ & $\begin{array}{l}\text { Techniques and Concepts } \\
\text { "In the creative cuisine field, there exists a phenomenon called } \\
\text { conceptual avant-gardist cuisine. As its name indicates, it } \\
\text { pretends to promote the progress of cuisine thanks to new } \\
\text { techniques and concepts." }\end{array}$ \\
\hline $\begin{array}{c}\text { Identified sources of } \\
\text { DPs }\end{array}$ & (No supporting verbatim found) & (No supporting verbatim found) & $\begin{array}{l}\text { Sources of Techniques and other elements } \\
\text { "Western cuisines, different from ours, as well as the so called } \\
\text { ethnical cuisines, can be an important part of the knowledge } \\
\text { heritage of a cook, who will adopt the most interesting findings of } \\
\text { those cuisines in terms of ingredients, elaborations, techniques } \\
\text { and even forms of eating. Hence, for the creator, the main appeal } \\
\text { of these cuisines, lies in their differences." }\end{array}$ \\
\hline
\end{tabular}

Type II generativity is a consequence of knowledge expansions guided by the generative heritage itself. Knowledge heritages with type II generativity invite the recipient designer to expand the knowledge heritage. They invite designers to nourish each category of the objects structure with new elements, or to create new categories of DPs. Two out of three analysed generative heritages showcase Type II generativity (Table 3): Escoffier and elBulli's generative heritage. Several characteristics of the knowledge heritage contributes to this generativity: First, they possess progress principles (PPs), that is, identified yet not satisfied FRs. Escoffier's generative heritage identifies PPs like simplicity, as well as client satisfaction. Even if he proposes some DPs related to FRs, like the reduction of the volume of the meal, or the diminution of the number of elements composing a garnish, he invites the recipient designer to continue to progress in this direction. elBulli identifies novelty, and the satisfaction of client's thirst of novelty as their PPs. Those principles guided their work and invite also the recipient to continue explorations in this direction. Second, they have knowledge voids (mDPs), that is, desired but missing DPs. Escoffier is in search of mDPs like food without inert matter in order to obtain concentrated nourishing principles, or pure starch for sauces in order to simplify and shorten the culinary operations to reproduce a Sauce. elBulli identifies missing DPs as new Techniques and new Concepts that could be combined in order to produce new types of dishes. mDPs acts as primers for future knowledge expansion, orienting recipient designers on where to invest their research efforts. As explained by Adrià, the discovery of new DPs like Concepts offers to the recipient designer a dimension of new possibilities 
(Adrià, 1998): "That's wonderful, the day somebody discovered that we could add an onion to an omelette. From that moment on, appeared the onion omelette. But the actual significant milestone occurred long time before, with the creation of the Concept "Omelette", which enabled besides the creation of the onion omelette, the appearance of an infinity of additional recipes created using a plethora of ingredients." And finally, in certain cases, the knowledge heritage orients the designer on how to "fill" the knowledge voids by highlighting the possible sources of DPs. That is the case of elBulli's generative heritage, which identifies traditional and foreign cuisine as sources of Products, Techniques, Concepts, etc.

\subsubsection{Generative heritages possess type III generativity}

Generative heritages showing type III generativity also guide the recipient designer through knowledge expansions that in turn become translated in new concepts. However, compared to type II generativity, those Concepts were not originally present nor in the recipient designer's knowledge base, nor in the transferred generative heritage. Knowledge expansion is primed, and new concepts can emerge throughout the exploration and creation of new knowledge. Two of the three analysed generative heritages show type III generativity (Table 4). Escoffier see in science a source of future evolutions: "In a word, cuisine, without ceasing to be an art, will become scientific and should submit its formulae, often still too empirical, to a method and a precision that will leave nothing to chance". The set of creative techniques of elBulli structure the acquisition of new knowledge in a controlled manner. Furthermore, type III generativity is also attained thanks to the introduction of new languages to describe the objects to be designed. In particular, elBullis' generative heritage make an effort to describe the reception of the dishes. They develop conceptual models about the influence of commensal's knowledge on the reception of the culinary experience and about the role played by the five senses with food (Adrià, 1998): "when contemplating a canvas, a sculpture, a movie, a piece of music, the produced emotion can be perceived through the senses. It is the same in the case of cuisine, where the senses enable our brain to receive this sensation". They develop a language about dishes presentation, forms, colours, temperatures and textures that the recipient designer should continue to construct in order to create new disjunctions.

Table 4. Generative heritages possessing type III generativity shows appetite for new languages for describing objects

\begin{tabular}{|c|c|c|c|}
\hline & François Pierre La Varenne & Auguste Escoffier & elBulli \\
\hline \begin{tabular}{|c|} 
Introduction of new \\
tanguages of DPs and \\
FRs
\end{tabular} & (No supporting verbatim found) & $\begin{array}{l}\text { Science as a new language for cooking } \\
\text { "In a word, cuisine, without ceasing to be an art, will } \\
\text { become scientific and should submit its formulae, often still } \\
\text { too empirical, to a method and a precision that will leave } \\
\text { nothing to chance" }\end{array}$ & $\begin{array}{l}\text { Language of the senses and about diner'ssenses interaction } \\
\text { with food } \\
\text { "The senses in gastronomy. When contemplating a canvas, a } \\
\text { sculpture, a movie, a piece of music, the produced emotion } \\
\text { can be perceived through the senses. It is the same in the } \\
\text { case of cuisine, where the senses enable our brain to receive } \\
\text { this sensation" } \\
\text { "VIEW: dishes presentation, forms, colours, identification of } \\
\text { the product. [...] TOUCH: Textures. Temperatures [...]" }\end{array}$ \\
\hline
\end{tabular}

\section{Conclusion}

In this paper, through the exploration of the characteristics of a generative heritage, we demonstrate that knowledge heritage integrates a generativity dimension. Besides the transfer of skills and competences, transferring knowledge implies also transferring unknowns, desires, value criteria, progress principles, and even creative reasoning. Furthermore, we verify that, as predicted by design theory, there exists a variety of generative heritages, that can be classified according to their generativity. In the case of cuisine, we see that during time, certain forms of generativity are developed, while others are lost or forgotten. We should keep in mind that the "recipient" of the generative heritage may play a paramount role in the transfer. The gain or lost in generativity, is probably related to recipient's previous knowledge base. Hence, it would be interesting to deepen the understanding of the interactions between previous recipient's knowledge base and the transferred generative heritage. Moreover, we characterize the generative heritages of cuisine. It would also be interesting to go further in the analysis of formalized generative heritages in other domains, like engineering, architecture and art handbooks. For those who wants to transfer their generative heritage, this paper gives them a general framework thanks to which 
they can keep in mind the importance of transferring conceptual models, as well as progress principles and knowledge voids. This paper also invites practitioners involved in knowledge management to think about new forms of knowledge management, more oriented to generativity. We have already begun to experiment new methods and processes of generative knowledge management in a luxury champagne house that will be the object of a future publication.

\section{References}

Adrià, F. (1998), Los Secretos de El Bulli, Altaya, Barcelona.

Adrià, F., Soler, J. and Adrià, A. (2014), elBulli 2005-2011, Phaidon.

Argote, L., Ingram, P., Levine, J.M. and Moreland, R.L. (2000), "Knowledge Transfer in Organizations: Learning from the Experience of Others", Organizational Behavior and Human Decision Processes, Vol. 82 No. 1, pp. 1-8. https://doi.org/10.1006/obhd.2000.2883

Arrow, K.J. (1969), "Classificatory Notes on the Production and Transmission of Technological Knowledge", The American Economic Review, Vol. 59 No. 2, pp. 29-35. https://doi.org/10.2307/1823650

Beaugé, B. (2013), Plats Du Jour: Sur L'idée de Nouveauté En Cuisine, Métailié, Paris.

Beverland, M. (2005), "Grafting brand authenticity: The case of luxury wines", Journal of Management Studies, Vol. 42 No. 5, pp. 1003-1029. https://doi.org/10.1111/j.1467-6486.2005.00530.x

Beverland, M. (2006), "The 'real thing': Branding authenticity in the luxury wine trade", Journal of Business Research, Vol. 59 No. 2, pp. 251-258. https://doi.org/10.1016/j.jbusres.2005.04.007

Briot, E. and De Lassus, C. (2014), Marketing Du Luxe: Stratégies Innovantes et Nouvelles Pratiques, Editions EMS.

Cohen, W.M. and Levinthal, D.A. (1990), "Absorptive capacity: A new perspective on learning and innovation", Administrative Science Quarterly, Vol. 35 No. 1, pp. 128-152. https://doi.org/10.2307/2393553

Dalkir, K. (2011), Knowledge Management in Theory and Practice, 2nd ed., The MIT Press, Cambridge, Massachusetts.

De Massis, A., Fratinni, F., Kotlar, J., Messeni Petruzzelli, A. and Wright, M. (2016), "Innovation Through Tradition: Lessons from innovative family businesses and directions for future research", Academy of Management Perspectives, Vol. 30 No. 1, pp. 93-116. https://doi.org/10.5465/amp.2015.0017

Escoffier, A. (1903), Le Guide Culinaire: Aide- Mémoire de Cuisine Pratique, Emile Colin, Paris.

Escoffier, A. (1907), A Guide to Modern Cookery, William Heineman, London.

Escoffier, A. (1912a), Le Livre Des Menus: Complément Indispensable Du Guide Culinaire, Imprimerie de E. Grevin, Paris.

Escoffier, A. (1912b), Le Guide Culinaire, Aide-Mémoire de Cuisine Pratique, 3rd ed., Imprimerie de E. Grevin, Paris.

Escoffier, A. (1921), Le Guide Culinaire: Aide-Mémoire de Cuisine Pratique, 4th ed., Flammarion, Paris.

Fink, B. (1995), Les Liaisons Savoureuses : Réflexions et Pratiques Culinaires Au XVIIIe Siècle, Publications de l'Université de Saint-Étienne, Saint-Etienne.

Goh, S.C. (2002), "Managing effective knowledge transfer: an integrative framework and some practice implications", Journal of Knowledge Management, Vol. 6 No. 1, pp. 23-30. https://doi.org/10.1108/13673270210417664

Hatchuel, A. (2005), "Quelle analytique de la conception? Parure et pointe en Design.”, Le design en question(s), Centre Georges Pompidou, Musée national d'Art modern, November 16-18, 2005, pp. 1-12.

Hatchuel, A. and Weil, B. (2009), "C-K design theory: An advanced formulation", Research in Engineering Design, Vol. 19 No. 4, pp. 19: 181. https://doi.org/10.1007/s00163-008-0043-4

Hatchuel, A., Le Masson, P., Reich, Y. and Subrahmanian, E. (2018), "Design theory: a foundation of a new paradigm for design science and engineering", Research in Engineering Design, Vol. 21 No. 1, pp. 5-21. https://doi.org/10.1007/s00163-017-0275-2

Hatchuel, A., Le Masson, P., Reich, Y. and Weil, B. (2011), “A Systematic Approach of Design Theories Using Generativeness and Robustness", Proceedings of the 18th International Conference on Engineering Design (ICED 11), The Design Society, Glasgow, pp. 87-97.

Hudson, B.T. (2011), "Brand heritage and the renaissance of Cunard", European Journal of Marketing, Vol. 45 No. 9/10, pp. 1538-1556. https://doi.org/10.1108/03090561111151880

Jansson, D.G. and Smith, S.M. (1991), "Design fixation", Design Studies, Vol. 12 No. 1, pp. 3-11. https://doi.org/10.1016/0142-694X(91)90003-F

La Varenne, F.P. (1651), Le Cuisinier François, Pierre David, Paris.

Le Masson, P. and Weil, B. (2013), "Design theories as languages of the unknown: insights from the German roots of systematic design (1840-1960)", Research in Engineering Design, Vol. 24 No. 2, pp. 105-126. https://doi.org/10.1007/s00163-012-0140-2 
Le Masson, P., Hatchuel, A. and Weil, B. (2016), "Design theory at Bauhaus: teaching 'splitting' knowledge", Research in Engineering Design, Vol. 27 No. 2, pp. 91-115. https://doi.org/10.1007/s00163-015-0206-Z

Leonard-Barton, D. (1992), "Core capabilities and core rigidities: A paradox in managing new product development", Strategic Management Journal, Vol. 13 No. S1, pp. 111-125. https://doi.org/10.1002/smj.4250131009

Madhavan, R. and Grover, R. (1998), "From Embedded Knowledge to Embodied Knowledge : New Product Development as Knowledge Management", Journal of Marketing, Vol. 62 No. 4, pp. 1-12. https://doi.org/10.2307/1252283

Mednick, S. (1962), "The associative basis of the creative process", Psychological Review, Vol. 69 No. 3, pp. 220 232. https://doi.org/10.1037/h0048850

Messeni Petruzzelli, A. and Savino, T. (2014), "Search, recombination, and innovation: Lessons from haute cuisine”, Long Range Planning, Vol. 47 No. 4, pp. 224-238. https://doi.org/10.1016/j.1rp.2012.09.001

Nagel, J.K., Pittman, P., Pidaparti, R., Rose, C. and Beverly, C. (2017), “Teaching bioinspired design using C-K theory”, Bioinspired, Biomimetic and Nanobiomaterials, Vol. 6 No. 2, pp. 77-86. https://doi.org/10.1680/jbibn.16.00013

Nonaka, I. (1994), “A dynamic theory of Organizational Knowledge Creation”, Organization Science, Vol. 5 No. 1, pp. 14-37. https://doi.org/10.1287/orsc.5.1.14

Opazo, M.P. (2016), Appetite for Innovation: Creativity and Change at elBulli, Columbia University Press, New York.

Pitt, M. and Clarke, K. (1999), "Competing on Competence: A Knowledge Perspective on the Management of Strategic Innovation”, Technology Analysis \& Strategic Management, Vol. 11 No. 3, pp. 301-316. https://doi.org/10.1080/095373299107375

Rambourg, P. (2010), Histoire de La Cuisine et de La Gastronomie Françaises, Tempus Perrin.

Schulze, A., Brojerdi, G. and von Krogh, G. (2014), "Those Who Know, Do. Those Who Understand, Teach. Disseminative Capability and Knowledge Transfer in the Automotive Industry", Journal of Product Innovation Management, Vol. 31 No. 1, pp. 79-97. https://doi.org/10.1111/jpim.12081

Scott, T.E. (1999), "Knowledge”, In: Runco, M.A. and Pritzker, S.R. (Eds.), Encyclopedia of Creativity, Vol. 2, Academic Press, San Diego, California, pp. 119-129.

Suh, N.P. (1990), The Principles of Design, Oxford University Press, New York.

Suh, N.P. (2001), Axiomatic Design: Advances and Applications, Oxford University Press, New York.

Szulanski, G. (1996), "Exploring Internal Stickiness: Impediments to the Transfer of Best Practice Within the Firm”, Strategic Management Journal, Vol. 17 No. S2, pp. 27-43. https://doi.org/10.1002/smj.4250171105

Szulanski, G. (2000), “The Process of Knowledge Transfer: A Diachronic Analysis of Stickiness”, Organizational Behavior and Human Decision Processes, Vol. 82 No. 1, pp. 9-27. https://doi.org/10.1006/obhd.2000.2884

Szulanski, G., Cappetta, R. and Jensen, R.J. (2004), "When and How Trustworthiness Matters: Knowledge Transfer and the Moderating Effect of Causal Ambiguity", Organization Science, Vol. 15 No. 5, pp. 600-613. https://doi.org/10.1287/orsc.1040.0096

Tsai, W. (2001), "Knowledge Transfer in Intraorganizational Networks: Effects of Network Position and Absorptive Capacity on Business Unit Innovation and Performance", The Academy of Management Journal, Vol. 44 No. 5, pp. 996-1004. https://doi.org/10.2307/3069443

Urde, M., Greyser, S.A. and Balmer, J.M.T. (2007), "Corporate brands with a heritage", Journal of Brand Management, Vol. 15 No. 1, pp. 4-19. https://doi.org/10.1057/palgrave.bm.2550106

von Hippel, E. (1994), “Sticky information' and the locus of problem solving: Implications for innovation”, Management Science, Vol. 40 No. 4, pp. 429-439. https://doi.org/10.1287/mnsc.40.4.429

von Krogh, G., Nonaka, I. and Nishiguchi, T. (2000), Knowledge Creation: A Source of Value, Palgrave Macmillan UK, London.

Wuestefeld, T., Hennigs, N., Schmidt, S. and Wiedmann, K.-P. (2012), "The impact of brand heritage on customer perceived value”, Der Markt, Vol. 51 No. 2-3, pp. 51-61. https://doi.org/10.1007/s12642-012-0074-2

Young, J.W. (2015), A Technique for Producing Ideas: A Simple Five Step Formula for Producing Ideas, CreateSpace Independent Publishing Platform.

Daniel Carvajal Pérez, Ph.D. candidate

MINES ParisTech, Centre de Gestion Scientifique

60 Boulevard Saint Michel, 75006 Paris, France

Email: daniel.carvajal_perez@mines-paristech.fr 